\title{
PROBLEMS OF RENOVATION \\ OF URBAN TERRITORIES IN THE RUSSIAN FEDERATION
}

\author{
Sergey Maksimov ${ }^{1}$ (D) \\ Georgi Zabunov²
}

DOI: https://doi.org/10.31410/LIMEN.2019.103

\begin{abstract}
The aim of the authors is to outline the main problems of urban renewal in contemporary Russia. The reasons for the transition to renovation as the main direction of urban development are revealed: changing structure of the economy, aging of the existing real estate, changing the real estate needs of the population and business. The experience of implementing renewal programs in developed countries such as the UK and Japan as well as in new EU member states such as Bulgaria is analyzed. The importance of public-private partnerships for successful urban renewal programs is emphasized.
\end{abstract}

Keywords: Urban renewal, Urban areas, Public-private partnership.

\section{INTRODUCTION}

$T^{\mathrm{n}}$ he high share of urban territories renewal is a distinctive feature of the construction activity in modern Russia. Interesting processes have been observed in housing for the period of transition to a market economy in the Russian Federation (RF). The last decade of the $20 \mathrm{c}$. was a period of a significant economic downturn and, therefore, of a sharp fall in construction. For instance, the volume of housing then decreased almost three times as much as the volume in the 1980 s. The recovery began in the first decade of the $21 \mathrm{c}$. What is typical of this period is the socalled spot building. It means that the creation of new real estates is done by filling the "gaps" within the boundaries of already built-up territories. During the second decade of this century, construction is already realized through the execution of projects for integrated development of new territories and the use of parcels that have not been developed yet. The English term for such parcels is greenfield. The transition to an integrated development of new territories allows to increase the volume of housing and to build adequate social and commercial facilities. However, there are negative phenomena as well: cities sprawl, traffic problems exacerbate, social facilities are often built a lot later than housing and all this usually leads to great dissatisfaction among homeowners. In the meantime, owing to the long periods of insufficient investment in major repairs and modernisation of existing real estate, they depreciate and whole urban areas are in poor condition (for example, the territory of the so-called "Grey belt" of Saint Petersburg). A new trend emerged in the second half of the second decade of the $21 \mathrm{c}$. A transition was made from integrated development projects of new territories to renewal (reconstruction, renovation) of built-up territories. The English term for this is brownfield. It should be taken into consideration that in specialised Russian literature the terms renewal and redevelopment are often opposed to each other even though authors do not find fundamental differences between them. Both terms mean a process of transformation of built-up territories in accordance with the changing needs of the society, business and population and involve the creation of estates and territories with modern infrastructure. This often requires a change in the functional purpose of individual sites or a certain number of real estates.

\footnotetext{
$1 \quad$ St. Petersburg state University, 199034, St Petersburg, 11 Lieutenant Shmidt Emb., Russia

2 UNWE - Sofia, 1700 Sofia, Student Town, Bulgaria
} 


\section{RENEWAL OF URBAN TERRITORIES IN RUSSIA}

The main reasons that necessitate the renewal of urban territories and the change in the direction of urban development are the changes in the structure of urban land use. These changes, in turn, are the result of structural changes in urban economy (e.g. reduced production of goods at the expense of services), physical and moral obsolescence of the existing urban real estates (primarily residential real estates), low efficiency of urban areas use (relatively low density of development in city centres), etc. What is of great importance is the need for expansion of construction opportunities, the use of renewal as a means of solving social problems by city authorities, etc.

The structure of Russian urban development implies a considerable need for renewal. A significant number of the residential buildings were built during a period known in Russia as the initial period of mass industrial housing. People call these buildings Krushchevkas and Brezhnevkas because they were built during the time of the leaders Krushchev and Brezhnev. According to the portal dom.mingkh.ru, about 307 thousand residential buildings with a residential area of 518 million square metres were built in the country within the two decades from 1950 to 1969 . This makes 8 million 160 thousand flats (Ministry of Housing and Communal Services, 2019). If we assume that at least $50 \%$ of these flats need renewal, then there should be built more than 4 million flats with a residential area of 250 million square metres. At the same time, according to the data from the central statistical service of Russia, Rosstat, 1070600 flats with a total area of 75,3 million square metres were put into operation in 2018 . This is $95,1 \%$ of the number of flats built in the previous year (flats with a total area of 79,2 million square metres were put into operation in 2017). A downward trend was observed because the flats built in 2017 amount to 98,7\% of those built in 2016. Building construction structure should not be neglected. The relative share of individual housing in the total area of completed homes was 43,1\% (Rosstat, 2019). In accordance with the Russian Federation's (RF) legislation, individual housing is a detached house of not more than 3 floors, with a garage, intended for a single family. This means that the volume of multi-storey housing is just over half of the total number of the homes put into operation. The need for renewal of big urban territories is obvious. For Saint Petersburg the situation is even more complicated. In this city, Krushchevkas were built during the period 1958-1970, i.e. for more than 10 years. 2400 buildings with a total area of around 9 million square metres were built over this period, which is almost 190000 flats. Actually, these are about $10 \%$ of all housing in the city with $12 \%$ of the urban population living in them (Region.Ru, 2003). Unfortunately, the renovation of the Krushchevkas is not the only problem the city is faced with. After 2020 the panel blocks that were built in the 1970s will be 50 years old. This is the conditional limit after which measures should be taken for their renovation. In the decade 1970-1979 more homes were built compared to the previous 20 years with a residential area of over 520 million square metres. By the middle of the next decade, the problem of their replacement will arise, so urban areas redevelopment seems to be the leading direction of urban development in Russia for many years and even decades. Redevelopment processes have started in Moscow, which provoked intense discussions among citizens, urban authorities, the business community and the general public. There have been discussed technical, organisational, economic and social problems. Federal legislation was introduced consisting mainly of bills for the renovation of the residential buildings in the Russian Federation. Now there are two major bills: the first one was tabled in the state Duma by a group of MPs in the autumn of 2018 and the second one - in the autumn of 2019 by the Legislative Assembly of Saint Petersburg.

The programmes for the urban renewal of Russian cities and the country as a whole are of key importance and require careful preparation. The legal and administrative mechanisms that 
should ensure the effective interaction of various institutions need thoughtful consideration. To achieve this, it is important to study and learn from the foreign experience. The experience of countries with long-standing renewal practice like Great Britain and Japan is very useful. The experience of countries like Bulgaria is valuable as well. Due to historical reasons, the problems that Bulgarian and Russian cities face are similar, even though the scale is different.

\section{THE EXPERIENCE OF THE UNITED KINGDOM}

A characteristic feature of the British approach to renewal is the active role of the central government. Renewal policy is considered an integral part of the national programmes aimed to solve a wide range of social issues, such as reducing unemployment and increasing job creation. The second significant feature is the fact that the government considers renewal programmes a factor for the development of regions far from the capital.

The renewal policy of the United Kingdom is the most long-standing one. The specialised journal Town Planning Review (TPR) has been published since 1910 and in its first issue started analysing the problems of the then British cities and the possibilities for solving them by using the tools of the concept of the Garden Cities which was popular at that time (Shaw \& Robinson, 2010). The period from the 1970s to the present day is of interest for the purposes of this study. It can be divided into three main stages.

The first stage of mass renewal in the country begins after the Conservatives came to power in 1979, when the central government started implementing an active policy of urban renovation. The government's ambition was to join forces with the private sector in order to solve urban problems.

The second stage begins in 1990 again under the Conservatives. This time the focus was on the simplifying and decentralising of renewal policy by attracting local authorities and private investors through centralised tenders.

The third stage begins in 1997, when the government put emphasis on the fact that renewal policy must be an ongoing process. As a result of the activities during the first two periods, a lot of British cities have developed successfully, but there have also been identified depressed areas that are difficult to change. However, according to the British government, there still has not been developed a good enough mechanism for interaction between the central government, local authorities and the private sector.

The Labour government that came to power in 1997 defined the implementation of an effective nationwide programme for renewal as one of its main objectives. A number of documents were adopted, the most important of which, according to British experts, is „The National Strategy for Neighbourhood Renewal" (Social Exclusion Unit [SEU], 1998), within which a lot of national programmes were developed: „Neighbourhood Renewal Fund“, „New Deal for Communities“, „Neighbourhood Management Pathfinders“. It is this legislative framework developed by the government that forms the basis of the renewal programme whose peak was reached in the period 2002 - 2011 (Shaw \& Robinson, 2010).

The renewal programme under „The National Strategy for Neighbourhood Renewal“ is intended to improve housing market, commercial real estate market and the infrastructure related to them in 25 country regions. The programme is aimed to solve problems like the improvement of 
housing quality, updating building layout and design, improving facilities, creating green spaces in and around neighbourhoods, eliminating serious imbalances between population needs and existing opportunities for construction of modern homes.

In order to implement the programme, there were set up governmental structures, such as Social Exclusion Unit (1997), Neighbourhood Renewal Unit (2001), Commission for Architecture and the Built Environment (1998), Urban Policy Unit (2001) and Academy for Sustainable Communities (2005). Their activity is coordinated with the adoption of key documents, such as Bringing Britain Together (1998), the above-mentioned National Strategy for Neighbourhood Renewal (2001), Sustainable Communities Plan (2003), Sustainable Communities: Homes for All (2005), Sustainable Communities: People, Places \& Prosperity (2005), Transforming Places, Changing Lives: A Framework for Regeneration (2008), etc. The main actors responsible for the programme implementation are: Regional Development Agencies, Local Strategic Partnerships, Urban Development Corporations, Urban Regeneration Companies, City Region Partnerships, Homes and Communities Agency. They ensure the efficient interaction between regional and local authorities, public and private organisations, ordinary citizens.

Providing adequate financing is the most serious problem with the programme implementation. For this purpose, are used the Neighbourhood Renewal Fund, Safe and Stronger Communities Fund, Area-Based Regeneration Grant, Working Neighbourhoods Fund, etc. The initial funding of the programme was provided by the central government: in February 2003 the British government allocated $£ 500$ million to support the new programme (Leather, Nevin, Cole, \& Eadson, 2012) and to ensure its implementation until 2006. Later the funding was extended to March 2008. The programme involved the demolition of old buildings and the construction of new ones as well as the reconstruction of existing ones. Decisions were made individually and regional specificity was taken into consideration. What is typical of the renewal programme of Great Britain is the fact that regional and local authorities made the lists of the neighbourhoods to be included in the programme. Homeowners could vote to participate or not to participate in the programme after reviewing the lists. If $2 / 3$ of the votes were in favour, there was a positive decision and inclusion in the programme.

Altogether, from 2002 to 2011 the government allocated $£ 2,2$ bn for renovation of homes, thus including over 780000 flats and over 1,9 million people living in them. In the beginning of the programme, each of the regions prepared a list of the main problematic areas and the funding included both small local projects and big urban ones.

By 2011, when the programme finished, there had been achieved the following results: reconstruction of over 108000 existing houses; attracting private investment for the building of over 15000 houses; preparing land for the future building of about 30000 modern real estates; improving housing quality; decreasing the number of depressed areas in the country; creating jobs in construction business. As a whole, the programme was successful.

\section{THE EXPERIENCE OF JAPAN}

The history of the modern programmes for housing renewal in Japan started in the 1980s. The first renewal wave in the 1980s, however, did not deliver impressive results because of the economic problems in the country in the 1990s. This was the reason why the projects were either suspended or cancelled. Since the practice of this period is considerable, the country became 
aware of the need to develop a legislative framework for further projects. Thus, in the beginning of the XXI c., the legislative framework for urban territories renewal had already been established. In 2002 the „Urban Renaissance Special Measure Law“, which defined the guidelines of the renewal programme in the country, came into effect. In accordance with the law, in the country and under the renewal programme there were identified 65 zones with a total area of over 6612 hectares, including 8 zones with an area of 2514 hectares in Tokyo (Shima et al., 2007). According to the government, the main challenge is attracting private investments for renewal programmes.

The major features of the renewal projects implemented in Japan are the following:

- Several organisations participated in the implementation of the projects. It is mandatory for them to include governmental structures at federal and urban levels, various governmental and non-governmental organisations as well as land and flat owners. A great role is played by the organisations set up by the participants who get involved at particular stages of the programme. For instance, in Tokyo there was set up an NGO organisation that discusses and approves a restructuring project.

- Initially, when implementing renewal programmes, 100\% homeowner consent was required in order to start the project. This blocked a lot of the projects since it is practically impossible to obtain the consent of all homeowners. That is why the law was revised later on and it was made possible to start a project with consent of $80 \%$ of the participants (Cho, 2011).

- A great number of private investors participate in the projects. Often local projects are riskier for private investors, who are the main actors in the reconstruction, because of the need to obtain a higher percentage of owner consent. Large-scale projects turn out to be more lucrative and easier to coordinate and, as a result, less risky. This is the reason why in the central parts of Tokyo as well as in other Japanese cities it is possible to find single old buildings and at the same time large redeveloped territories.

- Collective decision-making is considered very important. For example, when reconstructing a house, each of the tenants can make suggestions about the design of the new house similarly to the owners.

- To avoid the negative effects of the overheated economy that occurred in the 1990s, the government changed its investment strategy. Instead of direct investments in a given project, it started providing subsidies to the companies and investors involved in the renewal. To increase the effectiveness of project implementation, local authorities play a key role. It depends on them to give all the necessary permits swiftly and that is why they must be involved in the projects from the very beginning.

To sum up, it can be said that urban renewal measures have been successfully implemented in Japan.

\section{THE EXPERIENCE OF BULGARIA}

The experience of countries like Bulgaria is of interest to Russia. As a former country with central planning, Bulgaria faces problems similar to the Russian ones. Generally, the housing situation in the country is dissatisfactory, even though the rates of new housing provide normal reproduction of more than 2 homes per 1000 inhabitants on average. It is expected that by 2020 the rates of the period 2007-2009 will be reached and exceeded. At that period, 20 thousand homes were built annually. The major problem is that almost $27 \%$ of the homes (698 000) are 
in panel blocks which are depreciating quickly due to poor management and maintenance, but are still subject to renovation. A great number of the massive homes have depreciated as well. More than $75 \%$ of the flats in the country are in buildings that are over 30 years old (Mathema et al., 2017). The lack of maintenance of these buildings leads to the fast deterioration of their condition. Housing condition is constantly deteriorating due to the inadequate maintenance and management. This deteriorates the standard of living in these homes and changes urban environment. Due to the limited budget, the government is looking for complete solutions. Thus, the National Programme for Energy Efficiency of Multi-Family Residential Buildings was adopted in 2015. Meeting the high standards of energy efficiency of buildings is a criterion for successful renovation. This is an objective that is fully in line with EU's commitment to environmental issues. Buildings consume $40 \%$ of the total energy consumption of the EU. The reduction of this percentage is a priority (European Parliament and the Council, 2010).

The National Programme for Energy Efficiency of Multi-Family Residential Buildings was adopted by Decree № 18 of the Council of Ministers of 2 February 2015. In accordance with the Energy Efficiency Act, the programme coordinator is the minister of regional development and public works. These are not the first steps for renovation of old buildings in Bulgaria. Similar projects were started in 2007 and 2011, but their scope was limited and their nature was of a pilot experiment. The National Programme for Energy Efficiency involves a number of participants: Ministry of Regional Development and Public Works, Ministry of Finance, Bulgarian Bank for Development, municipalities, district governors and external contractors. The programme includes the whole territory of the country. Funding amounting to 2 bn Bulgarian leva ( $€ 1$ bn) was provided for its implementation. The programme was planned to be completed by the end of 2019. As of December 2018, implementation activities on practically all contracts under the programme had started, which was $98,8 \%$. The contracts included 2022 buildings. As of 31 December 2018, a total of 511 buildings (36 545 homes) were put into operation (Ministry of Regional Development and Public Works, 2019).

Regardless of these impressive results, a number of disturbing facts have been found out. Only a small number of Bulgarian citizens benefit from the programme but all taxpayers finance it. There are doubts about corrupt practices related to the implementation process. There are problems related to the quality of the construction activities. According to the official reports on the programme implementation [ $\mathrm{xxx}$ ], the cost of renovating a square metre of living space is similar and even higher than the cost of new construction. The programme was declared national but in Sofia, the city with the largest in number and area panel residential estates, there has been contracted the renovation of only 14 buildings.

Generally, the programme cannot be considered successful.

\section{CONCLUSION}

Summarising the foreign experience in implementing urban renewal programmes, suggestions can be made regarding the improvement of the effectiveness of such programmes in Russia. They are as follows:

- A federal law must be adopted that sets out the basic principles and approaches for implementation of renewal programmes. The law must take into account the possibilities and specificity of the regions and regulate the responsibilities of governing bodies at regional and local levels. 
- The interaction of federal, regional and municipal authorities, private investors and entrepreneurs, and urban community at all stages of programme implementation should be ensured: from its design to its final implementation. Potential conflicts must be anticipated and managed.

- Private investors should be attracted by using various tools: stimuli, subsidies, tax preferences and controlled interest rates.

- The views of all stakeholders should be taken into account not only at the stage of decision-making on whether to implement the programme, but also when defining its parameters after discussions at local and regional levels.

An adequate theoretical framework for research should be considered. Obviously, the research will be of interdisciplinary nature. The search of effective interaction between governmental bodies, business and the community involve economic analysis based on the new institutional economics. The clear distinction between official organisations and institutions broadens the scope of analysis. In this context, we consider institutions the historically established rules for interaction between the participants in the process. Thus, these interactions can be formalised by using qualitative and quantitative models. This allows to carry out an impact assessment of the change in the regulatory framework at different levels of government.

In any case, the lack of good will and willingness for cooperation cannot be compensated by good legislation only. Therefore, it is very important to choose an appropriate form of public-private partnership when implementing renewal programmes. There are no valid recipes and the specificity of all participants must be taken into account. A precondition for success is the high degree of transparency at all stages of the programme design and implementation.

\section{REFERENCES}

Cho, S. (2011). Urban transformation of Seoul and Tokyo by legal redevelopment project.

A|Z ITU Journal of the Faculty of Architecture. 8(1), 169 - 183. Retrieved from http://www. az.itu.edu.tr/azv8nolweb/15-cho-08-01.pdf

European Parliament and the Council. (2010). Directive 2010/31/EU of the European Parliament and of the Council of 19 May 2010 on the energy performance of buildings. Official Journal of the European Union. Volume 53, 18 June. doi: 10.3000/17252555.L_2010.153.eng

Leather, P., Nevin, B., Cole, I., \& Eadson, W. (2012). The Housing Market Renewal Programme in England: development, impact and legacy [Brochure]. Sheffield Hallam University: Centre for Regional, Economic and Social Research. Retrieved from http://ukregeneration. org.uk/wp-content/uploads/2012/01/HMR-legacy-paper-1-12.pdf

Mathema, A. S., Budovitch, M. M., Giteva-Gantcheva, D. K., Ellmauer-Klambauer, A., Mot, A. M. M., Vasileva, M. A. (2017). Bulgaria - Housing sector assessment: final report [Brochure]. Washington, D.C.: World Bank Group. Retrieved from http://documents.worldbank. org/curated/en/776551508491315626/Bulgaria-Housing-sector-assessment-final-report

Ministry of Housing and Communal Services. (2019). Housing information in Russia, Summary statistics 1900 - 2019. Retrieved from http://dom.mingkh.ru/\#.

Ministry of Regional Development and Public Works. (2019). Progress report on the implementation of the "National Program for the Energy Efficiency of Multi-Family Residential Buildings" in 2018 and Annex to the report. Retrieved from https:/www.mrrb.bg/ bg/doklad-za-napreduka-po-izpulnenieto-na-nacionalna-programa-za-energijna-efektivnost-na-mnogofamilni-jilistni-sgradi-prez-2018-godina-i-prilojenie-kum-doklada/ 
Region.Ru. (2003). Information Agency Region.Ru 2003. Retrieved from http://regions.ru/ news/1268602/

Rosstat. (2019). Russian Federal State Statistic Service 2019. Retrieved from https://www.gks. ru/bgd/free/B04_03/IssWWW.exe/Stg/d04/19.htm

Shaw, K., \& Robinson, F. (2010) UK Urban regeneration policies in the early twenty-first century: Continuity or change? Town Planning Review, 81 (2) 123 - 147. doi: 10.3828/tpr.2009.31

Shima, Hiramoto, Seta, Katayama, Kim, Cho, Matsutani. (2007, September). Tokyo's Largescale Urban Redevelopment Projects and their Processes. Paper presented at $43^{\text {rd }}$ ISOCARP Congress, Antwerp. Retrieved from http://www.isocarp.net/Data/case_studies/1040.pdf

Social Exclusion Unit. (1998). Bringing Britain Together: A National Strategy for Neighbourhood Renewal (Cm 4045). London: SEU. 